\title{
Effect of black cumin oil (Nigella sativa L.) on fresh fish (Barbus grypus) fillets during storage at $2 \pm 1{ }^{\circ} \mathrm{C}$
}

\author{
Emine OZPOLAT ${ }^{1 *}$, Muhsine DUMAN ${ }^{1}$
}

\begin{abstract}
It is important that the methods and materials used for to lengthen the shelf-life of food are simple, inexpensive and safe. For these reasons, herbal additives like cumin oil (Nigella sativa L.) have been preferred recently. Thus, the present study focuses on the influence of black cumin oil on chemical, microbiological and sensory quality of fish (Barbus grypus) fillets during storage at $2 \pm 1{ }^{\circ} \mathrm{C}$. Acceptability scores for sensory quality of all described treatment groups decreased with storage time. Defined limits for mesophilic bacteria and Total volatile basic nitrogen (TVB-N) were reached after $21^{\text {st }}$ days for the control group, after $24^{\text {th }}$ days for with $0.2 \%$ black cumin oil treated group and after $28^{\text {th }}$ days for with $0.4 \%$ and $0.6 \%$ black cumin oil treated groups. No difference was found among groups during storage in terms of defined thiobarbituric acid (TBA) values. Consequently, it was found that black cumin oil treated groups had longer shelf-life and higher sensory quality than the untreated control group.
\end{abstract}

Keywords: black cumin oil; Barbus grypus; Nigella sativa; shelf life.

Practical Application: Addition of black cumin oil in fish fillets resulted in longer shelf life and this method could be simple, commercially and safety.

\section{Introduction}

Biological composition of fresh aquatic food makes them immensely perishable and leads to fast declines in their quality. Also, these products are not able to be storaged for a long time under normal refrigeration conditions due to enzymatic activity and microbiological spoilage. Alternative methods have been studied to increase the shelf-life of stored fresh fish and to increase the economic value of these products to be able to satify the increasing demands and to decrease energy costs related to these products (Ashie et al., 1996; Kykkidou et al., 2009). Therefore, alternative sources of safe, effective and acceptable natural preservatives need to be explored. The use of natural antimicrobials such as organic acids, essential oils, plant extracts, and bacteriocins could be good alternatives to ensure food safety (Burt, 2004; Holley \& Patel, 2005; Emir Coban, 2010; Negi, 2012; Emir Coban \& Ozpolat, 2013). Nigella sativa L., is known as black cumin or black seed. Nigella sativa L. is a member of the Ranonculaceae family and native to some parts of the Mediterranean region. Dried black cumin seeds have been used in salads, breads, cheese, coffee and tea (Ustum et al., 1990; Arici et al., 2005; Ramadan, 2007). Black cumin oil has been shown to demonstrate antibacterial (Arici et al., 2005; Hanafy \& Hatem, 1991; Hassanien et al., 2013), antifungal (Khan et al., 2003) and antioxidant (Burits \& Bucar, 2000; Luther et al., 2007) activities.

The freshwater fish shibuta (Barbus grypus Heckel, 1843), is a cyprinid which is found along the Euphrates and Tigris Rivers in Turkey, Syria and Iraq and is abundant and commercially important (Oymak et al., 2008). It reaches a maximum size of $2 \mathrm{~m}$ and $60 \mathrm{~kg}$ (Zivotofsky \& Amar, 2006).

Limited data, however, are available with regard to the application of black cumin oil for extension of shelf life and quality during cold storage of fish. Hence, the aims of the present work were to determine the effects of black cumin oil on the shelf life of fresh Barbus grypus fillets during storage at $2 \pm 1^{\circ} \mathrm{C}$.

\section{Materials and methods}

\subsection{Sample preparation}

Black cumin oil (100\% oil) was purchased commercially from the Mecidefendi Company (Izmir, Turkey). Barbus grypus weighing $7-8 \mathrm{~kg} / \mathrm{fish}$ was caught during the period of January-February 2014 in the Keban Dam Lake. Fish were transported to the laboratory with ice in boxes. The fish were immediately gutted, filleted and washed. The fish fillets were divided into four treatment groups; control samples without added cumin black oil and samples treated with cumin black oil at a rate of $0.2,0.4$ and $0.6 \%$ oil (volume/weight of fish flesh; v/w). Aproximately $1.5-2 \mathrm{~kg} /$ fish were in each of treatment groups. Cumin black oil was added to the surface of fish samples in appropriate volumes using a micropipette, followed by mildly massaging the oil onto each sample using a gloved hand. Treatment groups were vacuum packed (high barrier nylon polyethylene bags) and stored at $2 \pm 1{ }^{\circ} \mathrm{C}$ until analysis on days $1,3,6,9,12,1518,21,24$ and 28 . The study was carried out in duplicate. 


\subsection{Microbiological analysis}

A sample of $10 \mathrm{~g}$ (each package) was taken aseptically from each sample, transferred to a stomacher bag and $90 \mathrm{ml}$ of sterilized peptone water (Buffer Peptone Water, LAB M) was added. The mixture was homogenized for $2 \mathrm{~min}$ with a stomacher (Stomacher 400, Lab. Blender, London, UK). Samples (0.1 ml) of serial dilutions of fish fillets homogenates were spread on the surface of agar plates. Total psychrophilic and mesophilic aerobic bacteria were determined on Plate Count Agar (PCA, Merck 1.05463) after incubation at $7{ }^{\circ} \mathrm{C}$ for 10 days and $30^{\circ} \mathrm{C}$ for three days, respectively. Lactic acid bacteria were determined on MRS Agar (Merck 1.10660) after incubation at $28{ }^{\circ} \mathrm{C}$ for two days. Enterobacteriaceae was determined on Violet Red Bile Glucose Agar (Oxoid CM 485) after incubation at $37^{\circ} \mathrm{C}$ for 1 day. Yeasts and molds were enumerated on Rose Bengal Chloramphenicol Agar (RBC, Merck 1.00467) after incubation at $25^{\circ} \mathrm{C}$ for five days. Microbiological data were transformed into the log of the number of colony-forming units (cfu/g) (Halkman, 2005).

\subsection{Chemical analysis}

The $\mathrm{pH}$ of samples was measured according to an AOAC method (Association of Official Analytical Chemists, 1990). Ten gram samples (a package from each groups) were homogenized with $90 \mathrm{ml}$ deionised water and the $\mathrm{pH}$ was measured with a digital pH meter (EDT.GP 353). Thiobarbituric acid (TBA) was determined according to the method of Tarladgis et al. (1960). TBA content was expressed as mg of malondialdehyde (MDA)/kg of fish flesh. Total volatile basic nitrogen (TVB-N, $\mathrm{mg} / 100 \mathrm{~g}$ fish flesh) was determined acording to the method described by Varlik et al. (1993).

\subsection{Sensory analysis}

Eight experienced panelists, who were academic staff and trained in sensory descriptors for fish flesh, evaluated the sensory quality of samples. The package from each treatment groups have been opened and evaluated the sensory quality. The sensory assessment of raw fish flesh was conducted using the Quality Index Method developed by Bonilla et al. (2007) with some modifications. The scheme consisted of six quality parameters (texture, mucus, leachate, odor, colour, brightness). A demerit score, which ranged from 0 to a maximum of 3 , where 0 represented the best quality and a higher score (3) indicated poorer quality, was used in evaluations. Fish samples (25 g) were cooked individually in a microwave oven at full power (1600 W) for $2 \mathrm{~min}$ and served hot to panelists. The sensory evaluations of cooked fish flesh were assessed according to the method of Amerine et al. (1965). Panelists were asked to score odour, taste, colour and texture of fish using a 1-10 acceptability scale (scale: 9-10, excellent; 7-8, good; 5-6, limit of acceptable; $\leq 5$, unacceptable). All the sensory evaluation were averaged.

\subsection{Statistical analysis}

All analytical determinations were on days $1^{\text {st }}, 3^{\text {th }}, 6^{\text {th }}, 9^{\text {th }}, 12^{\text {th }}$, $15^{\text {th }} 18^{\text {th }}, 21^{\text {th }}, 24^{\text {th }}$ and $28^{\text {th }}$. Experiments were replicated twice on different occasions with different fish samples. Each sample was analyzed three times and the mean calculated. Data were subjected to analyses of variance. The Tukey's honest significant difference procedure was used to test for differences between means $(\mathrm{p}<0.05)$ using SAS 6.1 (SAS Institute Inc., Cary, NC) (SAS Institute, 1999).

\section{Results and discussion}

\subsection{Assessment of microbiological parameters}

Changes in microflora of Barbus grypus flesh affected by different concentration of black cumin oil addition during storage period are shown in Figure 1.

The average initial number of mesophilic bacteria for all group samples $(3.2 \mathrm{log} \mathrm{cfu} / \mathrm{g})$ indicates that fisher were of acceptable quality. Control, $0.2 \%, 0.4 \%$ and $0.6 \%$ black cumin oil added samples exceeded the value of $7 \mathrm{log} \mathrm{cfu} / \mathrm{g}$ for mesophilic bacteria considered as the upper acceptability limit (International Commission on Microbiological Specifications for Foods, 1978) for fresh marine species on days 21, 24, 28 and 28 of storage, respectively (Figure 1a). The average psychrophilic bacteria count for the fillets was $3.77 \log \mathrm{cfu} / \mathrm{g}$. The number of psychrophilic bacteria increased with storage time, and in control group after the $12^{\text {th }}$ day the count was higher than in all of treatment groups $(\mathrm{p}<0.05)$ (Figure 1b). The count of lactic acid bacteria increased during the storage period and on the $15^{\text {th }}$ day the difference among groups (control and 3 treatment groups) was statistically significant $(\mathrm{p}<0.05)$. The rate of increase in lactic acid bacteria was the highest in control group $(\mathrm{p}<0.05)$ (Figure $1 \mathrm{c})$. The initial Enterobacteriaceae count in fillets was $1.3 \mathrm{log} \mathrm{cfu} / \mathrm{g}$. During storage, the Enterobacteriaceae count increased in all groups $(\mathrm{p}<0.05)$. The rate of increase in Enterobacteriaceae in treatment groups was lower than the control group and the treatment groups with $0.4 \%$ and $0.6 \%$ black cumin oil had a lower rate of increase in Enterobacteriaceae than the treatment group with $0.2 \%$ oil $(p<0.05)$ (Figure 1d). Initial yeast and mold levels were determined as $1.77 \log \mathrm{cfu} / \mathrm{g}$. The increase in yeast and mold counts in all groups was significant after the $12^{\text {th }}$ day $(\mathrm{p}<0.05)$. On the $15^{\text {th }}$ day of storage, the rates of increase in yeast and mold in the control and $0.2 \%$ treatment groups were higher than $0.4 \%$ and $0.6 \%$ groups $(\mathrm{p}<0.05)$ (Figure 1e). With all these results, it was determined that black cumin oil addition improved the microbiological quality and increased the shelf-life of fresh Barbus grypus fillets In terms of microbiological quality (mesophilic bacteria, psychrophilic bacteria, lactic acid bacteria, Enterobacteriaceae and yeats and mold) similar results of black cumin oil usage were reported (Arici et al., 2005; Hassanien et al., 2013). These studies showed (Arici et al., 2005; Hassanien et al., 2013) black cumin oil addition improved the microbiological quality.

\subsection{Assessment of chemical parameters and $\mathrm{pH}$}

Figure 2 shows the average values of the chemical parameters and $\mathrm{pH}$ values analysed on each sampling day. The initial $\mathrm{pH}$ value of the fish flesh was 5.96. $\mathrm{pH}$ increased significantly with storage time in all groups. The increase of $\mathrm{pH}$ values during the storage period may be attributed to the accumulation of ammonia and organic amine compounds and bacterial growth (Bensid et al., 2014; Schormüller, 1968). The control group had a higher $(\mathrm{p}<0.05) \mathrm{pH}$ value than other groups only on day 24 of storage. No difference 

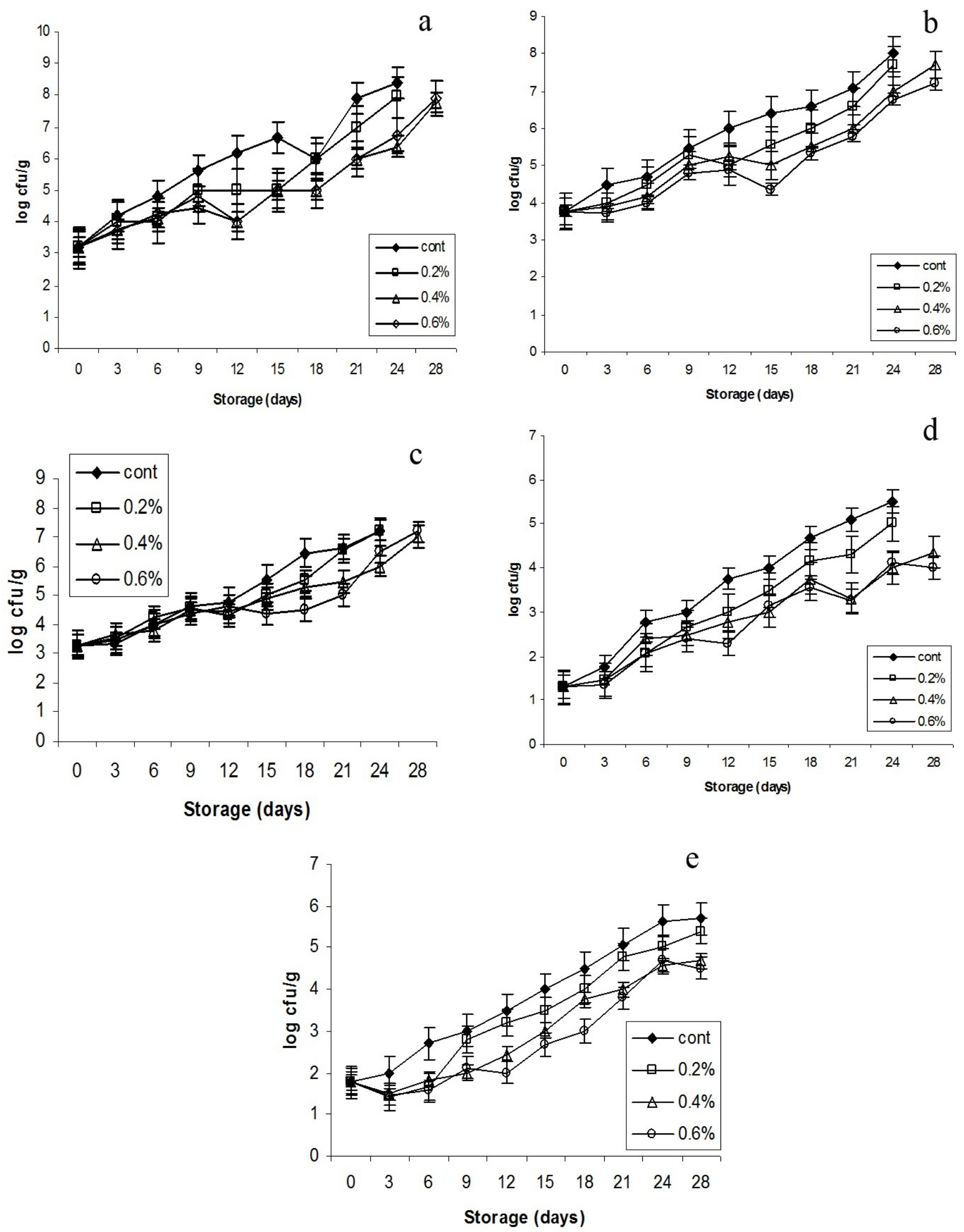

Figure 1. Changes in the counts of ( $\log _{10} \mathrm{CFU} / \mathrm{g}$ ) (a) mesophilic bacteria; (b) psychrophilic bacteria; (c) lactic acid bacteria; (d) Enterobactericeae; (e) yeats and mold: in the Barbus grypus flesh different concentration of black cumin oil addition during storage at $2 \pm 1{ }^{\circ} \mathrm{C}$. 
( $p>0.05)$ was observed throughout the storage period between black cumin oil treated groups (Figure $2 \mathrm{a}$ ).

The TVB-N is a measure of the ammonia, trimethylamine and dimethylamine formed from the breakdown of nucleotides and from the deamination of amino acids by microorganisms (Contreras-Guzman, 2002; Oliveira et al., 2010). According to Huss (1995) the acceptable TVB-N level is $35-40 \mathrm{mg} \mathrm{N} / 100 \mathrm{~g}$. At the begining of storage TVB-N values for fish fillets were determined at $18.2 \mathrm{mg} / 100 \mathrm{~g}$ for fish flesh. The TVB-N values were significantly different between control and treatment groups $(\mathrm{p}<0.05)$ on $21^{\text {st }}$ and $24^{\text {th }}$ days of storage. The values of TVB-N increased during the storage period and exceeded the acceptable limit on the $21^{\text {th }}$ day for the control group, $24^{\text {th }}$ day for $0.2 \%$ black cumin oil added group, $28^{\text {th }}$ day for $0.4 \%$ and $0.6 \%$ black cumin oil added groups $(\mathrm{p}<0.05)$. These results demonstrate that black cumin oil was effective in reducing the TVB-N values in the fish flesh (Figure 2b).

The thiobarbituric acid (TBA) test is generally used as a measure of lipid oxidation (Yu et al., 2002). TBA values among treatments followed similar increasing trends with storage period,
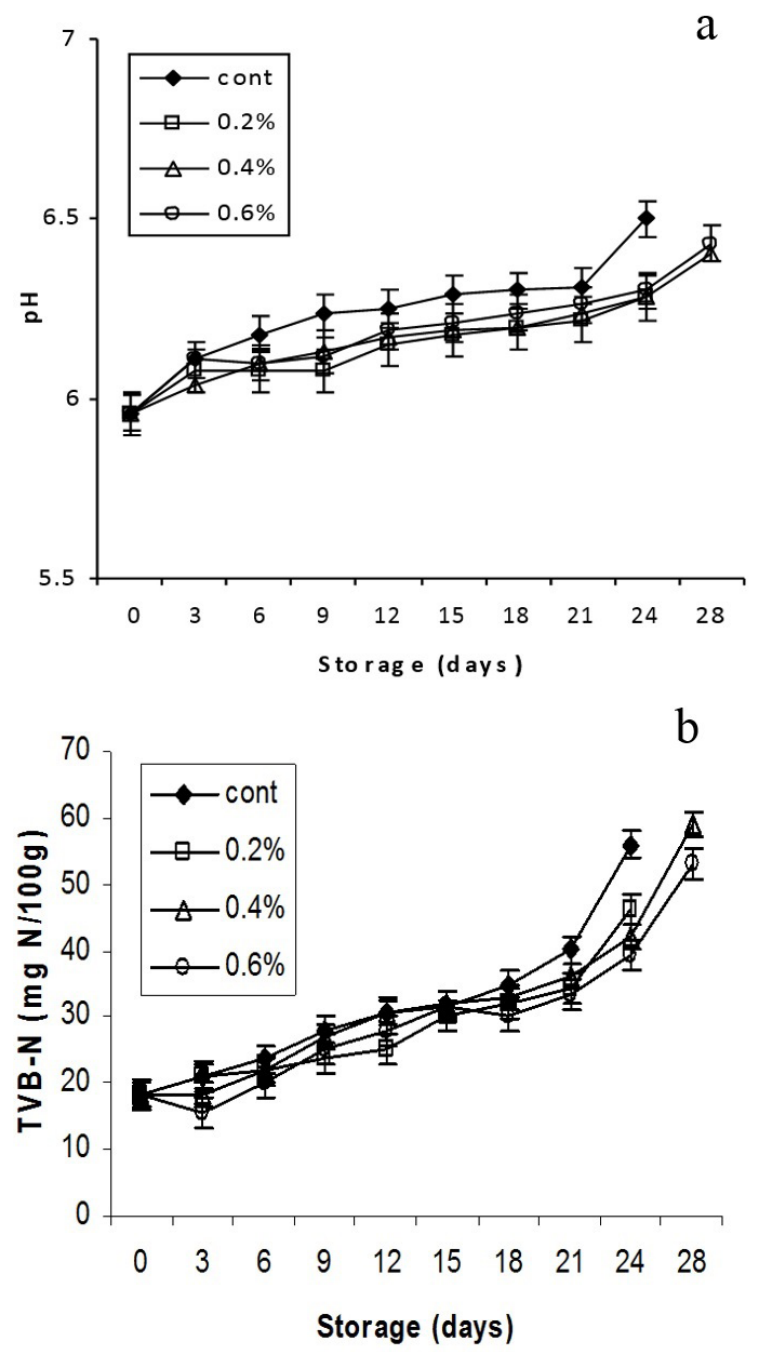

Figure 2. $\mathrm{pH}$ (a) and TVB-N (b) in the Barbus grypus flesh different concentration of black cumin oil addition during storage at $2 \pm 1{ }^{\circ} \mathrm{C}$. but values were all less than $0.5 \mathrm{mg}$ malonaldehyde $/ \mathrm{kg}$ ). All values were were lower than the limit value ( $5 \mathrm{mg}$ malonaldehyde $/ \mathrm{kg}$ ) during the storage period. It was determined that there was no significant differences in TBA values for the control and treatment groups during the study period ( $\mathrm{p}>0.05)$.

\subsection{Assessment of sensory analysis}

The sensory quality of raw and cooked Barbus grypus flesh was evaluated 2 days after fish were caught and on the $3^{\text {rd }}, 6^{\text {th }}$, $9^{\text {th }}, 12^{\text {th }}, 15^{\text {th }}, 18^{\text {th }}, 21^{\text {st }}$ and $24^{\text {th }}$ days of storage. Depending upon sensory analysis, the treatment groups with $0.4 \%$ and $0.6 \%$ black cumin oil had the longest shelf-life with 24 days. The group treated with $0.2 \%$ oil and the control group had 21 and 18 days long shelf-life, respectively. In addition, the treatment groups were highly preferred by panelists due to their desirable odour. The results of the sensory assesment indicated that shelf-life of fish flesh was affected by black cumin oil addition. (Figure 3). Similar results were seen in different studies in which positive effects of plant extracts (such as, thyme, oregano, clove and rosemary) on food (Ozyurt et al., 2011; Bensid et al., 2014).
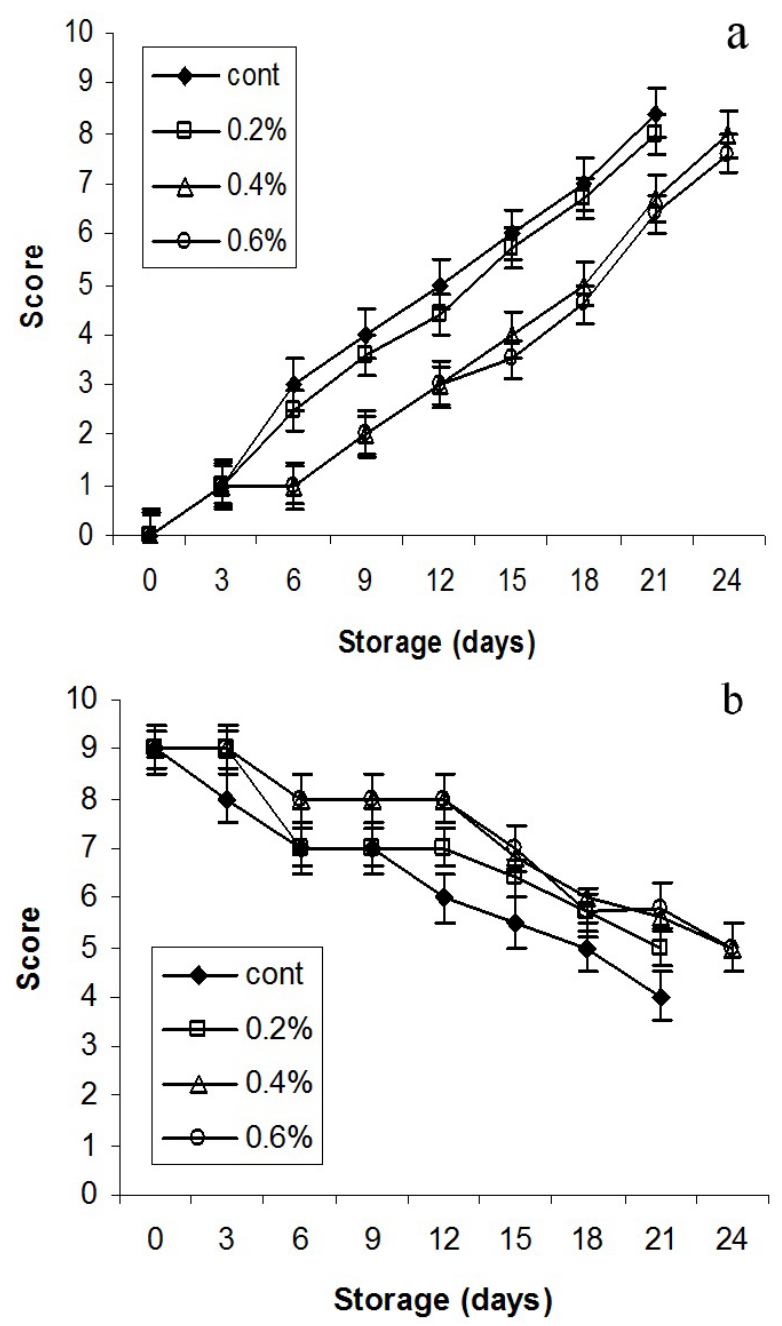

Figure 3. Sensory assessment of raw (a) and cooked (b) Barbus grypus flesh different concentration of black cumin oil addition during storage at $2 \pm 1{ }^{\circ} \mathrm{C}$. 


\section{Conclusion}

The results of this study suggest that black cumin oil no adverse effect of fish fillets and black cumin oil dose of $0.6 \%$ more longer shelf life and higher sensory quality than the other threated dose $(0.2 \%$ and $0.4 \%)$. Thus, black cumin oil has been usable of fish fillets as additive.

\section{References}

Amerine, A.M., Pongborn, R. M., \& Roessler, E. B. (1965). Principles of sensory evaluation of food. New York: Academic Press.

Arici, M., Sagdic, O., \& Gecgel, U. (2005). Antibacterial effect of Turkish black cumin (Nigella sativa L.) oils. Grasas y Aceites, 56(4), 259-262. http://dx.doi.org/10.3989/gya.2005.v56.i4.90.

Ashie, I. N. A., Smith, J. P., Simpson, B. K., \& Haard, N. F. (1996). Spoilage and shelf life extension of fresh fish and shellfish. Critical Reviews in Food Science and Nutrition, 36(1-2), 87-121. http://dx.doi. org/10.1080/10408399609527720. PMid:8747101.

Association of Official Analytical Chemists - AOAC. (1990). Official methods of Analysis of the Association of Official Analytical Chemists (15th ed.). Washington: AOAC.

Bensid, A., Ucar, Y., Bendeddouche, B., \& Özogul, F. (2014). Effect of the icing with thyme, oregano and clove extracts on quality parameters of gutted and beheaded anchovy (Engraulis encrasicholus) during chilled storage. Food Chemistry, 145, 681-686. http://dx.doi.org/10.1016/j. foodchem.2013.08.106. PMid:24128531.

Bonilla, A. C., Sveinsdottir, K., \& Martinsdottir, E. (2007). Development of Quality Index Method (QIM) scheme for fresh cod (Gadus morhua) wllets and application in shelf life study. Food Control, 18(4), 352-358. http://dx.doi.org/10.1016/j.foodcont.2005.10.019.

Burits, M., \& Bucar, F. (2000). Antioxidant activity of Nigella sativa essential oil. Phytotherapy Research, 14(5), 323-328. http://dx.doi. org/10.1002/1099-1573(200008)14:5<323::AID-PTR621>3.0.CO;2-Q. PMid:10925395.

Burt, S. (2004). Essential oils: their antibacterial properties and potential applications in foods- a review. International Journal of Food Microbiology, 94(3), 223-253. http://dx.doi.org/10.1016/j.ijfoodmicro.2004.03.022. PMid:15246235.

Contreras-Guzman, E. S. (2002). Biochemistry of Fish and Invertebrates (in Spanish). Santiago: Cecta-Usach Press.

Emir Coban, O. (2010). The effect of some essential oils on the shelf life of smoked and vacummed rainbow trout (Oncorhynchus mykiss) fillets (PhD thesis). Firat University, Elazig.

Emir Coban, O., \& Ozpolat, E. (2013). The effects of different concentrations of rosemary (Rosmarinus officinalis) extract on the shelf life of hotsmoked and vacuum-packed Luciobarbus esocinus fillets. Journal of Food Processing and Preservation, 37(3), 269-274. http://dx.doi. org/10.1111/j.1745-4549.2011.00645.x.

Halkman, A. K. (2005). Merck gida mikrobiyolojisi uygulamalari. Ankara: Basak Matbaacilik.

Hanafy, M. S. M., \& Hatem, M. E. (1991). Studies on the antimicrobial activity of Nigella sativa seed (black cumin). Journal of Ethnopharmacology, 34, 275-278. http://dx.doi.org/10.1016/0378-8741(91)90047-H. PMid:1795532.

Hassanien, M. F. R., Mahgoub, S. A., \& El-Zahar, K. M. (2013). Soft cheese supplemented with black cumin oil: Impact on food borne pathogens and quality during storage. Saudi Journal of Biological Sciences, 21(3), 280-288. http://dx.doi.org/10.1016/j.sjbs.2013.10.005. PMid:24955014.

Holley, R. A., \& Patel, D. (2005). Improvement in shelf life and safety of perishable fodds by plant essential oils and smoke antimicrobials.
Food Microbiology, 22(4), 273-292. http://dx.doi.org/10.1016/j. fm.2004.08.006.

Huss, H. H. (1995). Quality and quality changes in fresh fish (Food and Agriculture Organization Fisheries Technical Paper, 348). Roma: FAO.

International Commission on Microbiological Specifications for Foods ICMSF. (1978). Microorganisms in foods: their significance and methods of enumeration (2nd ed.). Toronto: University of Toronto Press.

Khan, M. A. U., Ashfaq, M. K., Zuberi, H. S., \& Gilani, A. H. (2003). The in vivo antifungal activity of the aqueous extract from Nigella sativa seeds. Phytotherapy Research, 17(2), 183-186. http://dx.doi. org/10.1002/ptr.1146. PMid:12601685.

Kykkidou, S., Giatrakou, V., Papavergou, A., Kontominas, M. G., \& Savvaidis, I. N. (2009). Effect of thyme essential oil and packaging treatments on fresh Mediterranean swordfish fillets during storage at $4^{\circ} \mathrm{C}$. Food Chemistry, 115(1), 169-175. http://dx.doi.org/10.1016/j. foodchem.2008.11.083.

Luther, M., Parry, J., Moore, J., Meng, J., Zhang, Y., Cheng, Z., \& Yu, L. (2007). Inhibitory effect of Chardonnay and black raspberry seed extracts on lipid oxidation in fish oil and their radical scavenging and antimicrobial properties. Food Chemistry, 104(3), 1065-1073. http:// dx.doi.org/10.1016/j.foodchem.2007.01.034.

Negi, P. S. (2012). Plant extracts fort the control of bacterial growth: efficacy, stability and safety issues for food application. International Journal of Food Microbiology, 156(1), 7-17. http://dx.doi.org/10.1016/j. ijfoodmicro.2012.03.006. PMid:22459761.

Oliveira, P. R. C. O. Fo., Favaro-Trindade, C. S., Trindade, M. A., Balieiro, J. C. C., \& Viegas, E. M. M. (2010). Quality of sausage elaborated using minced Nile tilapia submmitted to cold storage. Food Science and Technoloy, 67, 183-190.

Oymak, S. A., Dogan, N., \& Uysal, E. (2008). Age, growth and reproduction of the Shabut Barbus grypus (Cyprinidae) in Atatürk Dam Lake (Euphrates River), Turkey. Cybium, 32(2), 145-152.

Ozyurt, G., Kuley, E., Balikci, E., Kaçar, Ç., Gökdoğan, S., Etyemez, M., \& Ozogul, F. (2011). Effect of the icing with rosemary extract on the oxidative stability and biogenic amine formation in sardine (Sardinella aurita) during chilled storage. Food and Bioprocess Technology, 5(7), 2777-2786. http://dx.doi.org/10.1007/s11947-011-0586-7.

Ramadan, M. F. (2007). Nutritional value, functional properties and nutraceutical applications of black cumin (Nigella sativa L.): an overview. International Journal of Food Science \& Technology, 42(10), 1208-1218. http://dx.doi.org/10.1111/j.1365-2621.2006.01417.x.

SAS Institute. (1999). Version 6.1. Cary: SAS Institute.

Schormüller, J. (1968). Teil tiersiche lebensmittel eier, fleisch, buttermilch (Handbuch der lebensmittel chemie; Band III/2). Berlin: Springer Verlag.

Tarladgis, B. G., Watts, B. M., Younathan, M. T., \& Dugan, L. Jr (1960). A distillation method for the quantitative determination of malondialdehyde in rancid food. Journal of the American Oil Chemists' Society, 37(1), 44-48. http://dx.doi.org/10.1007/BF02630824.

Ustum, G., Kent, L., Chekin, N., \& Civelekoglu, H. (1990). Investigation of the technological properties of Nigella sativa (black cumin) seeds oil. Journal Association of Official Analytical Chemists, 67, 958-960.

Varlik, C., Ugur, M., Gokoglu, N., \& Gun, H. (1993). Su Urunlerinde Kalite Kontrol Ilke ve Yontemleri (Gida Teknolojisi Dernegi Yayın, 17). Istanbul.

Yu, L., Scanlin, L., Wilson, J., \& Schmidt, G. (2002). Rosemary extracts as inhibitors of lipid oxidation and colour change in cooked turkey products during refrigerated storage. Journal of Food Science, 67(2), 582-585. http://dx.doi.org/10.1111/j.1365-2621.2002.tb10642.x.

Zivotofsky, A. Z., \& Amar, Z. (2006). Identifying the ancient shibuta fish. Environmental Biology of Fishes, 75(3), 361-363. http://dx.doi. org/10.1007/s10641-006-6698-7. 